\title{
Special Essays
}

\section{From Damascus Gate to Shaikh Jarrah: The Palestinian Sovereignty Protests in East Jerusalem}

\author{
Mansour Nasasra \\ Senior Lecturer in Middle East Politics and IR, Department of Politics and \\ Government, Ben Gurion University of the Negev, Beer Sheba \\ mn261@exeter.ac.uk|mansor@bgu.ac.il
}

\begin{abstract}
The May 2021 Palestinian demonstrations in Shaikh Jarrah and Damascus Gate in occupied East Jerusalem and elsewhere in Arab towns inside Israel mark a dramatic shift in Israeli Palestinian conflict. These events in al Quds (Jerusalem) are directly linked to the Israeli policy of expelling more Palestinians from the borderland zone. In effect, such policy is used to control the most important geo-political space- the Shaikh Jarrah neighbourhood. In so doing, it imposes sovereignty over the Damascus Gate and its steps. The ongoing Israeli policy of imposing full control over the Shaikh Jarrah neighbourhood would mean challenging the historical role of diplomatic missions, international consulates and organizations, which represent many countries in the region. Based on ongoing research and interviews in East Jerusalem, this special essay argues that the Shaikh Jarrah protests are another manifestation of the ongoing struggle over control and sovereignty in the Old City and occupied East Jerusalem. It shows how the Shaikh Jarrah demonstrations display a unique picture of the conflict over borderland and geopolitics in al Quds.
\end{abstract}

\section{Keywords}

Shaikh Jarrah - East Jerusalem - Damascus Gate - demonstrations - Palestinians geo-politics - borders 
Habat Ayar, the May uprising, or Habat al Karama, or Habat al Quds of 2021, as it is called in the Palestinian lexicon, is the most recent and one of the crucial events of the Palestinian struggle against Israeli settler colonialism. Living in Jerusalem for years and observing the Ayar/May events, one could argue that the spontaneous ordinary demonstrations that took place in Jerusalem and elsewhere in Palestinian towns and cities inside Israel (for instance, Ledda, Ramle, Yaffa, Akka and Bir al-saba') marked a new phase in the history of the Palestinian struggle.

Since its occupation in 1967, al Quds has witnessed a massive number of demonstrations and everyday sumud practices by its Palestinian population. However, the recent demonstrations of al Karama during Ramadan 2021 have signalled a dramatic shift. The Israeli policy of expelling more and more Palestinians from the borderland zone, in effect trying to control the most important geo-political space - the Shaikh Jarrah neighbourhood-and to impose sovereignty over the Damascus Gate and its steps, is the key reason behind the protest movement of 2021.

Writing this paper from the avenues of Salah ad Din Street and the Shaikh Jarrah libraries and cafés in al Quds was an interesting ethnographic exercise; through this paper I attempt to tell the story of what I observed during the demonstrations of May 2021 or the habat al karama of ayaar. During my daily walk through the old city, from Damascus Gate to Shaikh Jarrah, I witnessed, observed, and recorded the daily demonstrations during Ramadan 2021 that took place in the streets of occupied East Jerusalem. This paper presents a range of historical narratives related to Jerusalem since 1967 and the Israeli Judaization campaign since Oslo in 1993 while also touching on the demonstrations of May 2021 around Damascus Gate (Bab al 'Amud) and Shaikh Jarrah. The demonstrations were led by local ordinary Palestinians far from any involvement of political leadership.

I argue that the Shaikh Jarrah and Damascus Gate demonstrations is another manifestation of the ongoing struggle over control and sovereignty of East Jerusalem between Israel and the Palestinians. Shaikh Jarrah displays a unique picture of the conflict over borderland and geopolitics in al Quds, while Damascus Gate represents the struggle over sovereignty in the old city and occupied East Jerusalem. In basic terms, from the narratives presented, the paper shows that the acts of Palestinians gathering and sitting on the stairs of Damascus Gate while drinking coffee and singing Palestinian national songs, is a form of Palestinian solidarity and protest against Israeli aspiration for full sovereignty in the city. Such everyday actions by the ordinary Palestinians in East Jerusalem, at Damascus Gate and in Shaikh Jarrah, are enough to say, from the local Palestinians' perspective, that Israel has no sovereignty over the space of Damascus Gate and the Borderland of Shaikh Jarrah. 
This paper also emphasizes that the conflict in the Shaikh Jarrah case is linked not just to a few properties in the neighbourhood, but extends to the recognized borders of 1967, embodying the geo-politics of the conflict in East Jerusalem and Palestinian resistance to the Israeli aspirations of full sovereignty over occupied East Jerusalem. Shaikh Jarrah is not simply another neighbourhood in East Jerusalem: it is currently the most important geo-political territory, located as it is in the borderland between West and East Jerusalem. Full control over Shaikh Jarrah would mean challenging the historical role of diplomatic missions, international consulates and organizations that represent many countries in the region. Israeli aspirations of full control over Shaikh Jarrah are yet another marginalization of the historical role of the neighbourhood during the Mandate and Jordanian rule in the city, a time when Jerusalem was more central than Amman.

\section{East Jerusalem Since Its Occupation in 1967: Isolation and Evisceration}

In the wake of the 1967 Arab-Israeli War, Israel occupied the Golan Heights, the West Bank, the Gaza Strip, and the Sinai Peninsula. East Jerusalem and an additional 64 square kilometers surrounding the city-which had belonged to 28 Palestinian villages in the West Bank — were annexed by Israel on 27 June, just over two weeks after the war ended. After this move, Israel extended its own laws to the entire area. As a price for annexing this territory, East Jerusalemites were partially integrated into Israeli society (Neve 2008). Even though Israel declared Jerusalem united and its capital, the UN and its member states continued to regard Jerusalem as occupied Palestinian land. Indeed, UN Security Council Resolution 478 (1980) clearly states that the annexation of East Jerusalem is a violation of international law (Yousef 2015). East Jerusalemites challenge Israeli sovereignty claims to East Jerusalem in their everyday actions even today.

Since annexing East Jerusalem in 1967, Israel has expropriated 35 percent of Palestinian-owned land for settlement building and other purposes (Nasasra 2019). In 2015, Jabareen estimated this to constitute an area of $22,571 \mathrm{~km}^{2}$ in East Jerusalem (Jabareen 2015). This facilitated the expansion of Jewish-Israeli settlements in the heart of the Arab space including occupying houses in the middle of Arab neighborhoods such as Shaikh Jarrah, Ras al 'amud, Silwan, the Muslim and Christian Quarters of the old city, At-Tur (Mont of Olives), Wadi al Joz, Jabal al Mukabbir and others (OCHA 2017; Nasasra 2019). Israeli settlements were constructed in East Jerusalem from the very beginning of the occupation, so that by 2017 there were more than 200,000 settlers ( 38 percent 
of the total Jewish population in Jerusalem) in East Jerusalem, who reside in 15 settlements (UNOCHA 2014).

The situation in East Jerusalem has deteriorated since the Oslo agreement, leaving the city in a very fragile political position. During the Oslo negotiations, Israeli and Palestinian teams both agreed that Jerusalem would be one of the subjects to be dealt with during the permanent status talks. Indeed, the Declaration of Principles (DOP) states that "it is understood that these negotiations shall cover remaining issues, including: Jerusalem, refugees, settlements, security agreements, border, relations and cooperation with their neighbors, and other issues of common interest," (cf. Turner 2019).

Since Oslo and the exclusion of Jerusalem from the Accords, Israel has consolidated its control over East Jerusalem and has managed to create "facts on the ground" before any potential final status resolution can be reached. Being the weaker party, the Palestinians' status was subsequently reduced to simply trying to survive in their everyday lives. Indeed, according to Adnan al-Hussaini, the former Palestinian governor of East Jerusalem, by 2014, Palestinians in East Jerusalem resided in only 13 percent of the overall territory of Jerusalem (Nasasra 2019). Donald Trump's statement in December 2017 that Jerusalem is the capital city of Israel has heightened the isolation of East Jerusalem from the West Bank and Gaza, leaving Palestinian Jerusalemites alone in their daily struggle against Israel's occupation and Judaization strategies. By declaring Jerusalem to be the capital of Israel, Trump made it clear that the city is now no longer part of the peace negotiations, further emphasizing the exclusion of the city from the Oslo Accord.

The evisceration of East Jerusalem accelerated after Oslo due to the effects of Israel's policies of "silent" transfer - revoking ID cards, preventing family reunification, house demolitions, lack of building permits, high taxes, and the continuing fragile status of residency - which has led to the "hidden" deportation of East Jerusalemites beyond the Separation Barrier into the West Bank and further afield (Nasasra 2019).

Not only has the daily life of East Jerusalemite Palestinians been made tenuous by these bureaucratic strategies, but the ongoing violence and aggression of the state towards the inhabitants affects all levels of the community, including children and women (Shalhoub-Koverkian 2015). After Oslo, Israel expedited the process of annexing Palestinian land in East Jerusalem, with the aim of excluding its Palestinian population. East Jerusalemites today are thus separated from the rest of the Occupied Palestinian Territories (OPT) but are also not integrated into West Jerusalem. Indeed, Yacobi and Pullan argue that the most striking and worrying part of Israeli policies in East Jerusalem are the 
restrictions on Palestinian development, the expulsion activities and house demolitions, and the lack of building permits (Haim 2014).

Following the signing of the Oslo Accords, Palestinian political institutions were able to operate officially, but not for long. Only a few years after Oslo, the PA was proscribed from functioning in Jerusalem, leaving a leadership and power vacuum. By limiting the PLO's access to Jerusalem and closing a significant number of its main institutions, such as Orient House and the leading educational institution of the directorate of education in Jerusalem (Mudiryat al Tarbiyya in al Quds), thus weakening the PLO's presence in Jerusalem and fragmenting the Palestinian body politic, Israel sent a clear message that the PLO would not be allowed to have a political base in the city. This affected other Palestinian institutions, too, including human relief, economic, and educational and cultural organizations and services, as well as civil societies representing women, tourist organizations, media and TV channels (Palestine TV), youth, and prisoners. Many Palestinian institutions in East Jerusalem were forced to move their bases to Ramallah and or beyond the separation wall such as al-Ram or at least outside Jerusalem's municipal borders.

\section{Shaikh Jarrah and Its Borderland: The Centre of International Institutions and Palestinian Organizations}

Walking through the streets of Shaikh Jarrah with its beautiful Palestinian houses and heritage, it is easy to recognize the importance of the neighbourhood in terms of its geo-political location, diplomatic status, and historical centrality during the Jordanian presence and the Mandate. In terms of space, it is only a ten-minute walk from Shaikh Jarrah to Damascus Gate via Nablus Road, which indicates how strategic is the Shaikh Jarrah location and its direct link to the old city. Shaikh Jarrah also connects the old city to the northern neighbourhoods of Jerusalem such as Shufaat and Beit Hanina and further to Ramallah and the north of the West Bank via Salah al Dien Street and Nablus Road. Its geo-political location made it a key target for Israeli settler colonial policies. The struggle in Shaikh Jarrah is not only about properties and houses that are historically and legally owned by Palestinians, it is part of a process of disconnecting it from the rest of the old city and linking it to the French Hill and Mount Scopus (Jabal al Masharif). Targeting Shaikh Jarrah is about controlling the northern entrance of Jerusalem and tightening Israeli control over the old city.

Containing the historical mosque of Shaikh Jarrah, renamed after one of the Emirs, of Salah al Dien al Ayubi of Jerusalem, Shaikh Jarrah is one of the most historical neighbourhoods of Jerusalem. Shaikh Jarrah is a borderland 


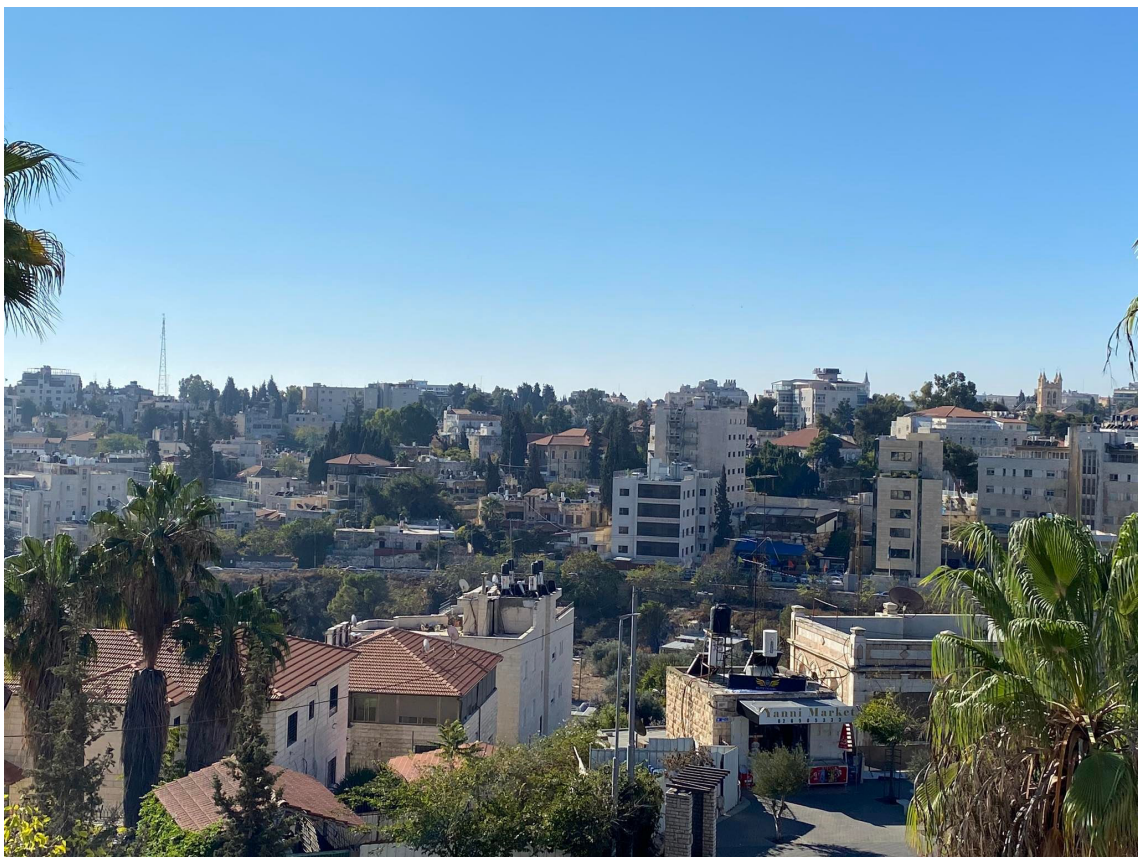

FIGURE 1 An image of Shaikh Jarrah taken from the Mount of Olives road (Jabal al Zayton). Photo by the author, 2021

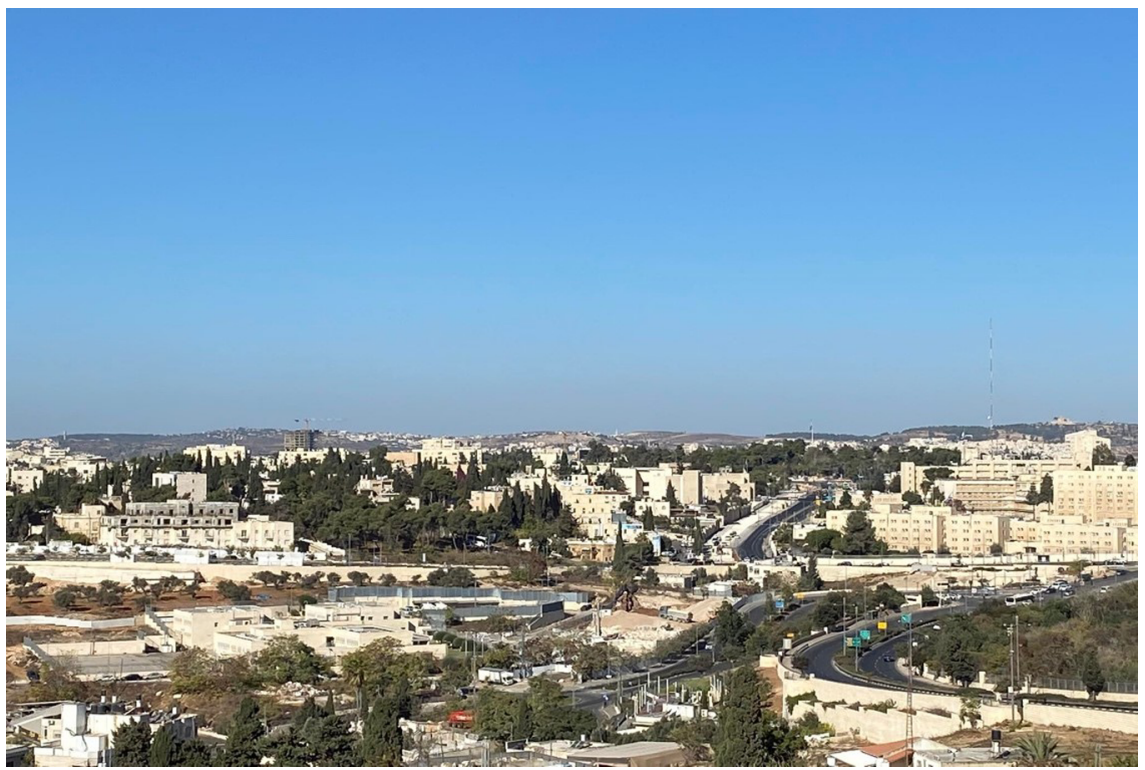

FIGURE 2 The geopolitical location of Shaikh Jarrah. Photo by the the author, 2021 
zone, a status immortalized by a famous restaurant there called Borderland. It is just a few minutes from the historical Mandalbaum gate, which was used by Jordanian and Israelis until 1967 to manage the entrance of people and traffic to East and West Jerusalem.

In terms of historical buildings and its administrative importance for Palestinians after the fall of the western part of the city, Shaikh Jarrah today is home to a number of Palestinian and international organizations, NGO s, international consulates, diplomatic missions, hospitals, libraries and historical sites.

Shaikh Jarrah is the neighbourhood that includes a number of national Palestinian symbols and international organizations, namely the Orient House and Hind al Hussaini College, the Palestinian Heritage Museum, St George's Hospital, the French hospital of mar Yousef, the British School of Archaeology (the Kenyon), the Ambassador Hotel, and the Palestinian National Theatre (al Hakawati), to name but a few. Leading Palestinian organizations are also located in Shaikh Jarrah, e.g. Palestinian Academic Society for the Study of International Affairs (Passia), a number of Awqaf historical schools, orphan

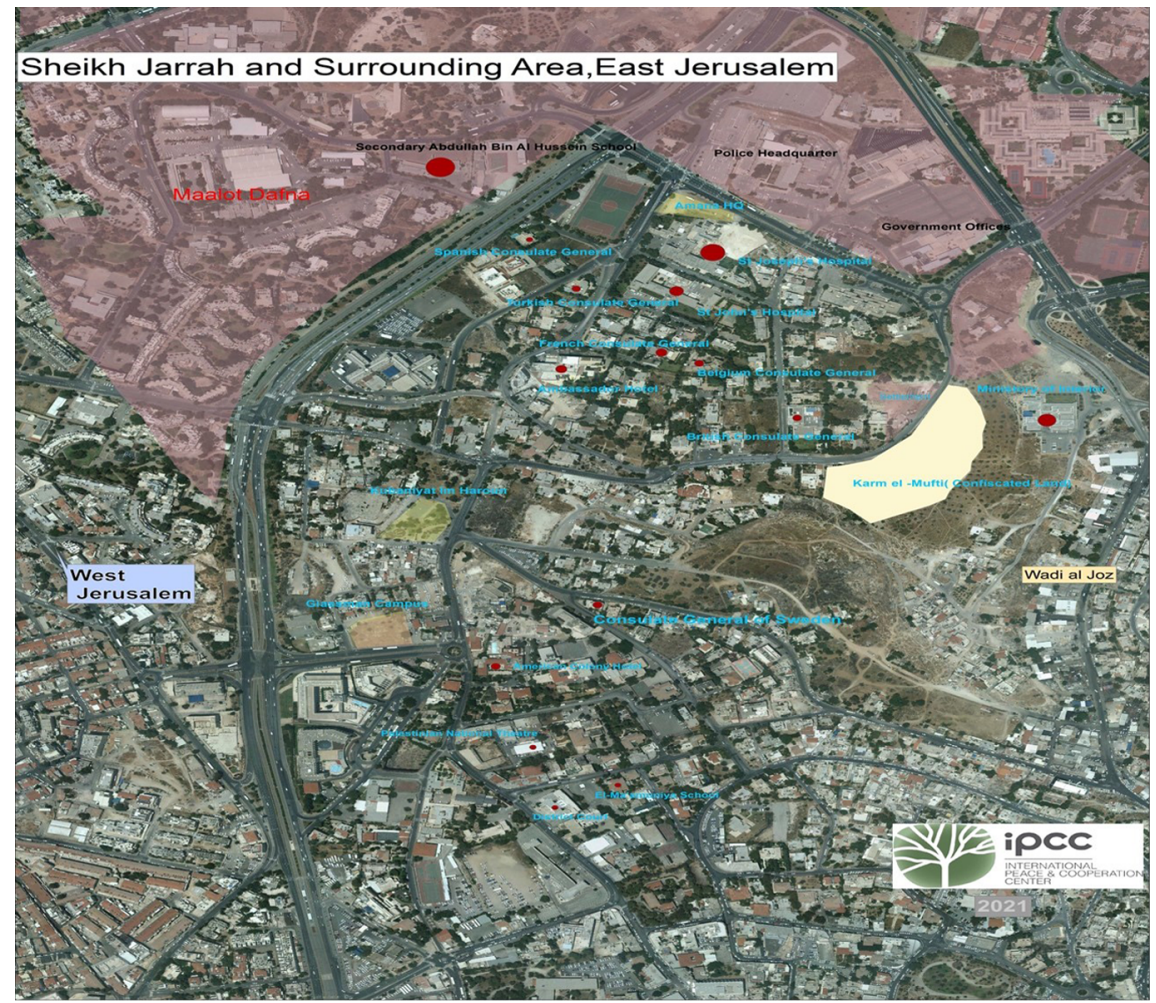

FIGURE 3 Map of the Shaikh Jarrah. COPYRIGHT IPCC, JERUSALEM, 2021 


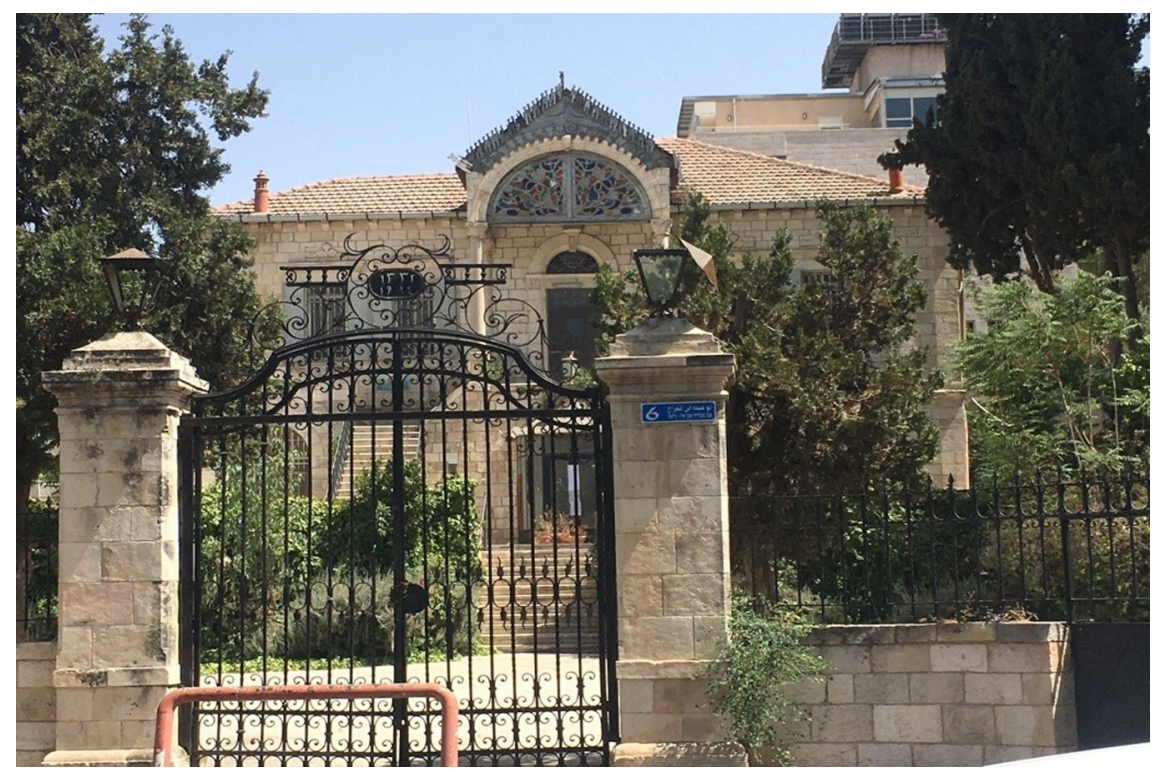

FIGURE 4 The Orient House in Shaikh Jarrah. Photo by the author, 2021)

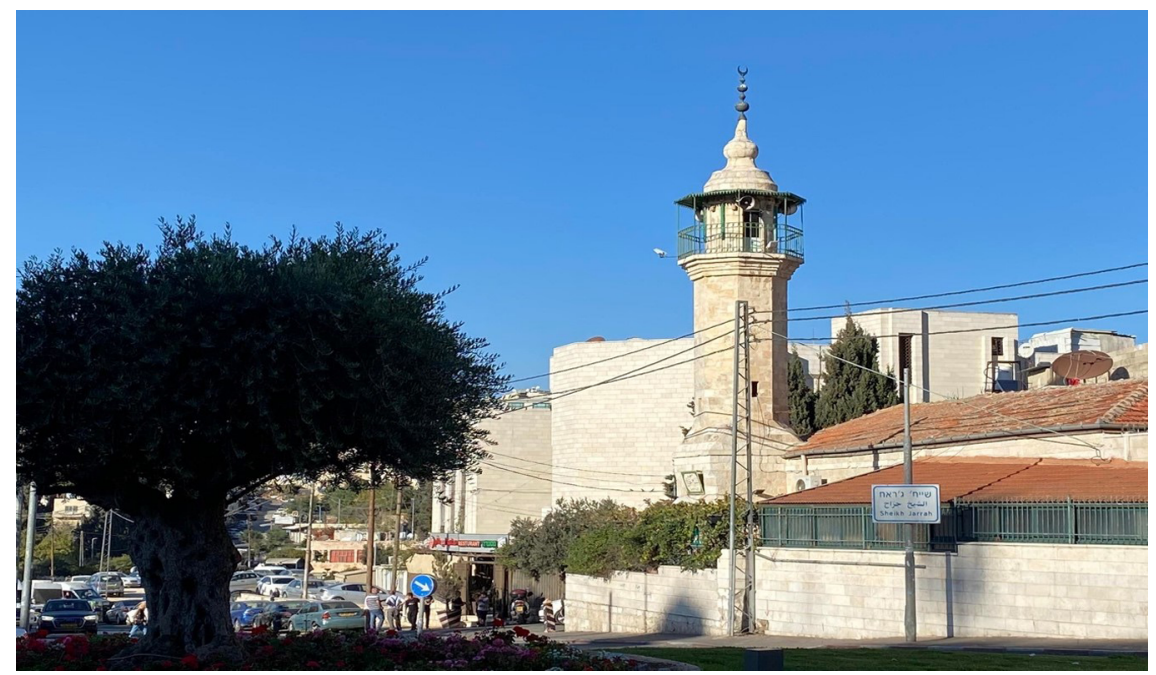

FIGURE 5 Image of the historical mosque of Shaikh Jarrah, built in 1895. Photo by the author, 2021)

children's school, Khalil al Sakakini school, Abdallah Ben al Hussain school, the historical mosque of Shaikh Jarrah (see image), and a history that is linked to the dynasty of Salah ad Din al Ayubi in Jerusalem. The neighbourhood was connected to the Grand Mufti of Jerusalem, Haj Amin al Hussaini, and other 
leading Palestinian figures during the Mandate, such as Raghib al Nashashibi after whom an exclusive avenue next to the British Consulate was named. The history and memory of Palestinian resistance during the Mandate is still present in the avenues and streets of Shaikh Jarrah. In fact, by targeting the neighbourhood, Israel targets Palestine's history of struggle and resistance to British colonialism in the city and memories of the Great Revolt that took place there.

Leading Palestinian families have historically populated the neighbourhood and today the Nashashibis and Hussainis, including the Palestinian former mayor of Jerusalem Adnan al Hussaini, live there. Other buildings in the neighborhood belong to local families such as Ghosha, Jarallah, the house of Rabbah al Hussaini (now the American Colony), the Palestinian Heritage Museum), the library of Issaf al Nashahibi, Dar al Tifl al' 'Arabi, and more. The famous Shepherd Hotel (owned by the Hussaini family) was also located in the neighbourhood and was occupied by Israel in 1967. In 2001, the hotel, which was an important Palestinian symbol, was destroyed; the Israelis built 20 houses for settlers on its ruins. Erasing the history of the shaikh Jarrah and its historical sites such as the Shepherd Hotel is part of the ongoing judasiation policies of the East Jerusalem.

The neighbourhood is also home to a significant number of diplomatic missions, consulates and international organizations that service Palestinian communities. These include the Turkish, Belgian, Armenian, French, Spanish, British, and Italian consulates, the European Union and Quartet offices, OCHA offices, the offices of the World Health Organization (wHO), the International Red Cross and Red Crescent offices, Food and Agriculture Organization of the United Nations (FAO), Young Women's Christian Association (YWCA) the Fredrich Nauman Stiftung offices, Rosa Luxemburg offices, and offices of the Norwegian Refugees Council (NRC) and UNRWA. This signifies the strategic and historic importance of the neighbourhood. According to Nazmi al Joabeh, pre-1967, Shaikh Jarrah also hosted the Iraqi, Lebanese, Saudi, Egyptian, and Syrian consulates (Jubeh 2021).

The fact that Shaikh Jarrah has housed such a significant number of international and Palestinian institutions since prior to 1967 demonstrates the strategic political position of the neighbourhood. The geo-political and borderland position of Shaikh Jarrah has made it the site of conflict between Israeli settler colonial policies and Palestinian sumud and national aspirations. 


\section{What's the Conflict about in Shaikh Jarrah? Palestinians Stuck between Jordanian and UNRWA Programs and Israeli Settler Plans}

Walking through Shaikh Jarrah, it is easy to spot the growing number of settlers in the neighbourhood and their occupation of a few Palestinian houses. When you see settlers living in Palestinian homes, for instance the one on Ibn Jubair Street of Shaikh Jarrah, it raises the question of how settlers became residents of the Palestinian neighbourhood of Shaikh Jarrah. Conquering Palestinian houses and settling settlers in Ibn Jubair street of Shaikh Jarrah summarizes the whole debate of evicting and erasing the natives from their homeland in a settler colonial context (cf. Wolfe 1997, 2016; Raef 2016; Mahmoud 2020; Areej 2021).

When speaking to the people of Shaikh Jarrah, it was clear that some of these Palestinian families were refugees expelled from their homes in Haifa, Sarafand, Jaffa, and elsewhere. It is said that the UNRwA and the Jordanian government secured their housing and living in Shaikh Jarrah. The properties in the area were managed by the "Jordanian Custodian of Enemy Property" until the occupation of east Jerusalem in 1967 by Israel.

According to recent reports released by the Royal Committee for Jerusalem, the land that is under threat of being evacuated and expropriated in Shaikh Jarrah is the area called Karm al Ja'onni. This space constitutes around 18 dunums. Another 8 dunums, called Kubaniet Umm Haron, are also under threat of expropriation. This area has been registered as waqf land since 1814 (The Royal Committee for Jerusalem Affairs, 2021).

The Royal Committee for Jerusalem mentions in its reports that Jordan contracted an agreement with the UNRWA in 1954. The agreement states clearly that the Jordanian government committed to building 28 residential houses and flats in Shaikh Jarrah to hand to families in 1956. The families covered by the agreement were refugees from 1948 are the same families being threatened with displacement today. The agreement between the UNRWA and the Jordanian government included an article that stated, "the residents will pay a symbolic rent, after three years from building the houses, the ownership will be handed to the residents themselves." Subsequently, the residents of Shaikh Jarrah paid 300 Jordanian dinars to the Jordanian government to register the houses under their names but the war of 1967 and the occupation of East Jerusalem brought this process to an end (The Royal Committee for Jerusalem Affairs, 2021). On the other side, as mentioned by Reiter and Lehrs (2010), the houses were built on a land owned by two Jewish trusts (e.g. Nahalat Shimon settler Organization). Obviously, Jewish settler organizations claimed that they had owned the disputed land since 1875 . However, Ottoman laws prevented foreigners from buying land or properties in Jerusalem without obtaining official orders from the 
Ottoman government. In this situation, the settlers' argument and claim is weak and cannot be true (The Royal Committee for Jerusalem Affairs, 2021).

Today, both the UNRWA and the Jordanian government have legal responsibilities to protect the status of the families of Shaikh Jarrah in a territory that was historically under Jordanian administration but is occupied by Israel since 1967. In an interview with MK Sami Abu Shehadeh during a demonstration in Shaikh Jarrah, he stated that "The story that Jewish settlers owned land in Shaikh Jarrah in 1948 is not true. The families in Shaikh Jarrah that are under a threat of being evacuated, they owned land and properties before 1948 in Haifa, Yafa, Lydda, Ramle, and even in the western part of Jerusalem. Most of them have documents of their properties and also land deeds. So, if Israeli respects the fact that Palestinians have ownership documents, they must allow the Shaikh Jarrah families (if they are considered as refugees) to go back to their houses and land inside Israel today and West Jerusalem." Abu Shehadeh clearly means that if settlers can claim properties in Shaikh Jarrah before 1948, then Israel must allow the refugees in Shaikh Jarrah to go back to the towns and villages where their legally owned properties and houses are located. As Abu Shehadeh emphasised, this is a political case, "it has nothing to do with the law and land properties but is part of the policy of expelling Palestinians from their land and bringing in settlers instead of them," (Interview with M K Abu Shehadeh, Shaikh Jarrah, 2021). In fact, the point of MK Shehadeh was made clear by Reiter and Lehr already in 2010. The price that Israel is likely to pay in the case of settling Jews in Arab neighbourhoods in East Jerusalem such as Shaikh Jarrah is significant, including "potential demands for legal restitution of property that was Palestinian-owned before 1948" (Reiter \& Lehrs 2010: 71). The settlers claim for properties and land ownership in Shaikh Jarrah (located in occupied east Jerusalem) pre 1948 opens up new avenues for the Palestinians elsewhere to claim their confiscated properties in West Jerusalem and inside Israel.

\section{The Everyday Demonstrations in Shaikh Jarrah}

As a result of the Israeli settler colonial policies and evacuation orders on the local families in Shaikh Jarrah, massive demonstrations erupted in occupied Jerusalem starting from Damascus Gate and spreading to Shaikh Jarrah and further to Palestinian cities and towns inside Israel, the West Bank and Gaza. The peaceful demonstrations and solidarity with the families of Shaikh Jarrah were unprecedented. Solidarity with the families in Shaikh Jarrah was witnessed every day in the neighbourhood and at Damascus Gate. Despite the Israeli 

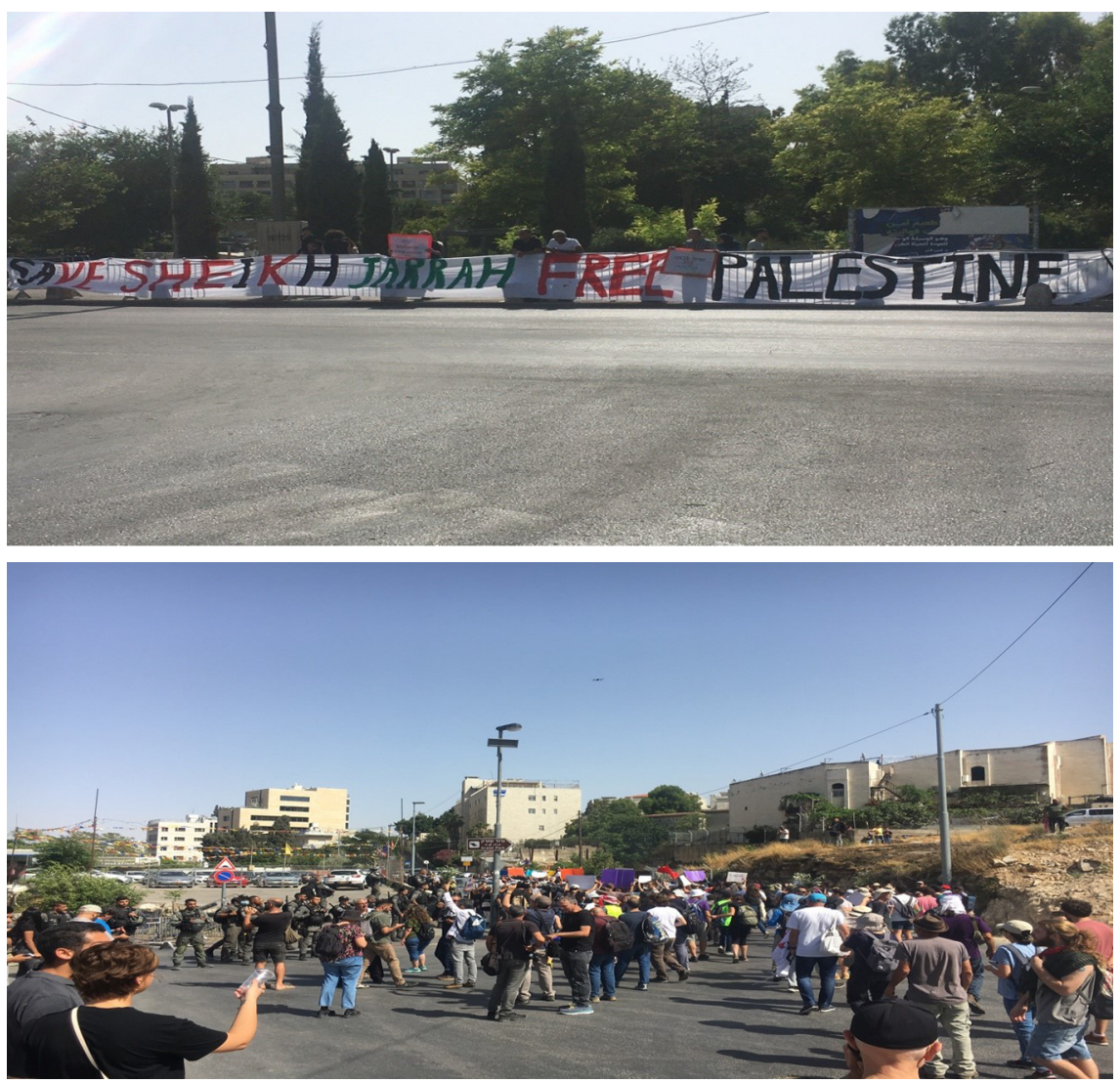

FIGURE 6 Demonstrations in support of Shaikh Jarrah. Photos by the author, 2021

police barricading the neighbourhood and only allowing residents access after showing their ID, hundreds of youths were able to organize daily Iftar dinners in front of the houses that were under evacuation orders. The Ramadan nights became a solidary act of support with Shaikh Jarrah that spread to Arab towns in Israel and elsewhere in Palestine.

Daily clashes erupted between Jewish settlers and Palestinian youth. The Israeli settlers were supported by $\mathrm{MK}$ Itamar Ben Gver who decided to open his parliamentary office in the main street of Shaikh Jarrah, which led to the escalation and spread of protests and violence across the Green Line and in the Arab towns. Ben Gver was perceived as a key instigator of the escalation of violence in Shaikh Jarrah and elsewhere.

In solidarity with Shaikh Jarrah, Jews and Arabs organized demonstrations in front of the neighbourhood, including demonstrations of the Israeli Left on Fridays. The High Arab Committee of the Palestinians in Israel also organized several demonstrations in front of the neighbourhood. 
The peaceful daily campaign of Shaikh Jarrah brought thousands of Palestinians to visit the neighbourhood each day. When I visited, I saw visitors from international organizations, local Arab leaders, Arab MK s and political figures from the Palestinians in Israel and even Israeli Left figures. The committees who visited Shaikh Jarrah including youth and women's delegations from Palestinian communities, students, and many others. Local and international media were present, covering the demonstrations and speaking to local families in Shaikh Jarrah despite the Israeli blockade.

During the protest and efforts to stop the escalation in East Jerusalem and inside Israel, many international organizations and activists reached Shaikh Jarrah and stood in support of their cause. I also observed the presence of several international teams and organizations in June 2021, including the head of the UNRWA, Philippe Lazzarini (Commissioner-General of UNRWA).

Local youth leaders of the Shaikh Jarrah neighbourhood emerged as key figures in the demonstrations, namely Muna and Mohammad al Kurd, whose
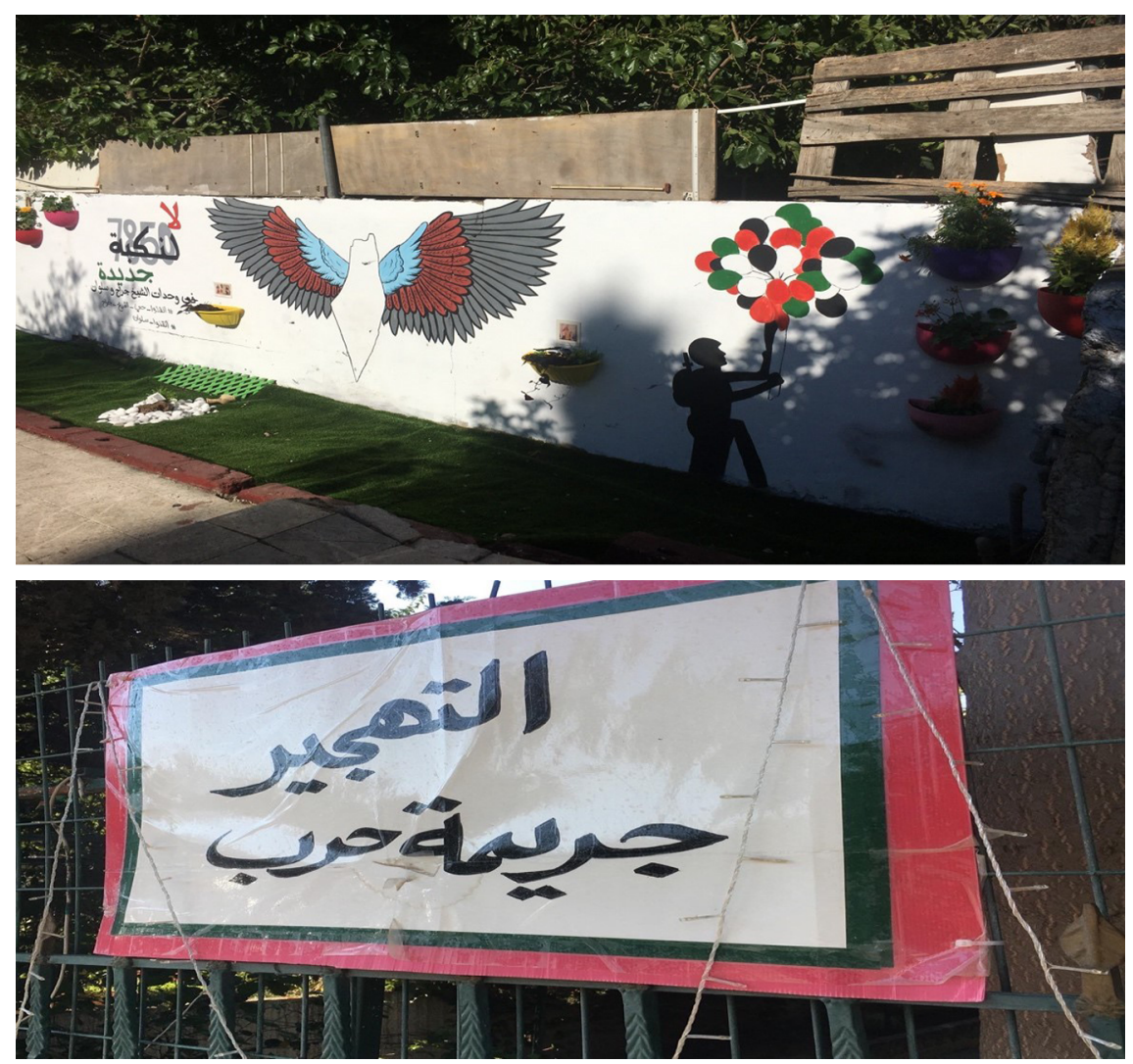

FIGURE 7 Slogans in Shaikh Jarrah, stating that "transfer is war crime" and "No to another Nakba". Photos by the author, 2021 
house was under threat of being controlled by the settlers. As part of their successful social media campaign, Muna and Mohamed were chosen by The Times as two of the 100 most influential figures in 2021 (Edwards 2021). In fact, Muna, a Bir Zeit student, managed to mobilize thousands from all over the world, spreading the message of Shaikh Jarrah and justice for the families. Muna's story tells us that a Palestinian youth leader can emerge from the heart of the struggle, challenging the Palestinian political leadership that has been mostly absent in East Jerusalem since the death of Faisal al Hussaini.

Writing in The Times magazine, Charlotte Edwards argued that "Muna and Muhammad al Kurd are 23-year-old siblings who have become social media stars. They are famous worldwide for live streaming the violence they witness on their streets in the Shaikh Jarrah neighbourhood," (Edwards 2021). The twins, who are followed on social media by two million people around the world, are going from one event to another - from Nazareth to South Africa campaigning for their Quds and Shaikh Jarrah, trying to generate solidarity to stop the evacuation of their families from Shaikh Jarrah.

Slogans against evacuation were posted at the entrance to Shaikh Jarrah, such as "transfer is a war crime," "no to transfer," "this is our land." Paintings and graffiti also adorned walls signifying poetry and songs, and even a small library materialized in the streets of Shaikh Jarrah, all of which are forms of protest the displacement and forced evictions of the families. The Palestinian flag was painted over the walls of the neighbourhood, and balloons were released, emblazoned with Palestinian flag colours. Israeli soldiers were seen trying to confiscate the balloons that represented the Palestinian flag colors (see images).

\section{The Steps of Damascus Gate in Support of Shaikh Jarrah: The Sovereignty Protest}

\section{"Sitting on the Stairs of Damascus Gate is an Act of Palestinian Sovereignty"}

One of the key sites of demonstrations for Shaikh Jarrah emerged on the steps of Damascus Gate and quickly became the focus of peaceful daily protests in East Jerusalem. The first signs of demonstrations in support of the families of Shaikh Jarrah started after the Israeli police fenced off the steps, trying to prevent people from gathering there during the Holy Month of Ramadan. Youth, men, and women started to gather on the steps despite the Israeli police's crackdown, chanting and displaying slogans calling for the metal fences to be removed and for the plaza to be opened for people to sit and enjoy the Ramadan atmosphere after the Iftar. After a few days of demonstrations, the 


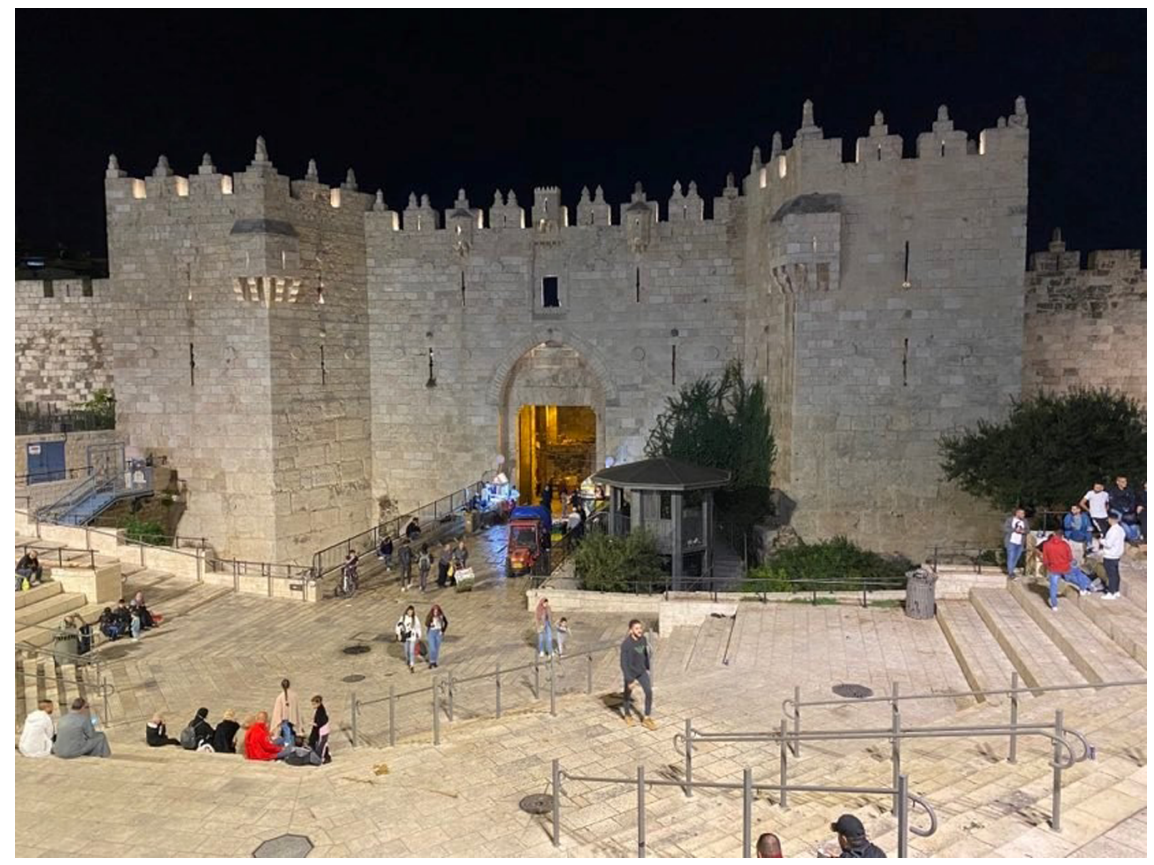

FIGURE 8 The key site of demonstrations, Damascus Gate/Bab al 'Amud. Photo by the author, 2021

police were forced to take down the fences from the steps of Damascus Gate. After liberating the steps of Shaikh Jarrah, thousands of youths, started to march and sing national songs at Damascus Gate in support of Shaikh Jarrah. The demonstrations took place every night during Ramadan, their peak being the 27th of Ramadan when the Israeli police stopped busloads of worshipers from arriving in Jerusalem. This drove people to march from main street close to the town of Abu Ghosh to Jerusalem, sending a clear message that they would arrive in Jerusalem, even walking.

As a result of the successful and unprecedented peaceful and sumud campaign of Shaikh Jarrah and the Damascus Gate sovereignty campaign, the Israeli Supreme Court became involved in the matter, trying to reach a decision that would calm the streets of Jerusalem. In August 2021, the Court ruled in favour of an ambiguous compromise. The Israeli Supreme Court proposed a compromise suggesting that Shaikh Jarrah families will be given the status of "protected tenants" at the mercy of the Israeli settler organization of Nahalat Shimon. The families of Shaikh Jarrah delivered a formal statement on November o2 stating that "we stand firm in our refusal to compromise on our rights despite the lack institutional guarantees that would protect our presence as Palestinians in occupied Jerusalem". (Statement of Shaikh Jarrah 
families, o2 November 2021). Despite the resistance of the Shaikh Jarrah families to the Court proposal, the case is still ongoing in the Supreme Court and will remain so for a long time, despite the problematic proposal that was suggested and rejected by the Shaikh Jarrah families. The resistance of the shaikh Jarrah families to the court proposal sends a clear message to the Palestinian public elsewhere that "the sumud of Shaikh is the sumud of al Quds".

\section{Conclusion}

A few conclusions can be drawn from the case of Shaikh Jarrah and the Damascus Gate protest. First, the May/Habat Ayar uprisings have erased the Green Line, at least psychologically, and unified the struggle that took place in Palestinian towns and villages in Israel, the West Bank, Gaza and elsewhere. Second, the demonstrations were led by a generation of youth and motivated by social media and the dignified campaign of a post-Oslo generation. Third, the uprising was linked directly to sovereignty over East Jerusalem and the Damascus Gate, not only to properties in Shaikh Jarrah. The Damascus Gate became the key Palestinian symbol of sovereignty in East Jerusalem. In fact, the act of sitting and singing Palestinian national songs on the steps of Damascus Gate is a statement by the Palestinians of occupied Jerusalem that they hold sovereignty over the gates of the old city. Shaikh Jarrah, moreover, was the most crucial geo-political and borderland space linked to Israeli settler colonial policies of reshaping the borders of 1967 and isolating the Shaikh Jarrah neighbourhood from the old city and the rest of the Palestinian population in East Jerusalem and elsewhere.

\section{Bibliography}

Areej Sabbagh-Khoury, 2021. Tracing Settler Colonialism: A Genealogy of a Paradigm in the Sociology of Knowledge Production in Israel. Politics and Society, pp. 1-40.

Charlotte Edwards, 2021. Gen Z Twins of Jerusalem (2 million followers and Counting). The Times Magazine, pp. 41-45.

Haim, Yacobi, et al. (2014). The Geopolitics of Neighborhood: Jerusalem's Colonial Space Revisited. Geopolitics 19(3):1-26.

ICAHD (2013). Israel's Policy of Demolishing Palestinian Homes Must End: ICAHD Submission to the UN. The Israel Committee Against House Demolitions (ICAHD) website. http://icahd.org/2013/o3/о3/israels-policy-of-demolishing-palestinianhomes-must-end-icahd-submission-to-the-un/ (accessed June 20, 2017). 
Nazmi Jubeh, 2021. Shaikh Jarrah: A struggle for survival (In Arabic), pp. 34-66. Institute for Palestine Studies.

Mahmoud, Mamdani, 2021.Neither Settler nor Native: The Making and Unmaking of Permanent Minorities. Belknap Press: An Imprint of Harvard University Press.

Mansour, Nasasra (2019). Occupied East Jerusalem since the Oslo Accords: Isolation and Evisceration. Mandy Turner (ed.), From the River to the Sea:Palestine and Israel in the Shadow of "Peace." Lanham: Lexington Books. pp. 213-244.

Mandy Turner (2019). From the River to the Sea: Palestine and Israel in the Shadow of "Peace." Lanham: Lexington Books.

Nadera Shalhoub-Koverkian (2015). Children: A Universalist Perspective for How Israel Is Using Child Arrest and Detention to further its Colonial Settler Project. International Journal of Applied Psychoanalytic Studies 12(3): 223-244.

Neve, Gordon (2008). From Colonization to Separation: Exploring the Structure of Israel's Occupation. Third World Quarterly 29(1), pp. 25-44.

OCHA 2017. Significant increase in risk of displacement in East Jerusalem. OCHA website. https://www.ochaopt.org/content/significant-increase-risk-displacementeast-jerusalem (accessed March 29, 2018).

Patrick Wolfe, 1997, "History and Imperialism: A Century of Theory, from Marx to Postcolonialism”. The American Historical Review 102,2. pp. 388-420.

Patrick Wolfe, 2016. The Settler Complex: Recuperating Binarism in Colonial Studies Paperback. UCLA-American Indian Studies Center.

Raef, Zreik, 2016. When Does a Settler Become a Native? (With Apologies to Mamdani). Constellations Volume 23, Number 3, 2016. John Wiley \& Sons Ltd.

Reiter, Yitzkah and Lior Lehrs, 2010. The Shaikh Jarrah Affair: The Strategic Implications of Jewish Settlement in the Arab Neighborhood in East Jerusalem. The Jerusalem Institute for Israeli Studies, Jerusalem.

The Royal Committee for Jerusalem Affairs, 2021. A Special Report about the Shaikh Jarrah (In Arabic), Amman. https://rcja.org.jo/\%D8\%AA\%D9\%82\%D8\%A7\%D8\% B1\%D9\%8A\%D8\%B1/.

UnCTAD (2013). The Palestinian Economy in East Jerusalem: Enduring Annexation, Isolation and Disintegration. Geneva: United Nations Conference on Trade and Development. http://unctad.org/en/PublicationsLibrary/gdsapp2012d1_en.pdf.

UnOCHA, (2011). East Jerusalem: Key Humanitarian Concerns. (UNOCHA, March 2O11), 12-13.

UNOC HA (2014). East Jerusalem: Key Humanitarian Concerns. United Nations Office for the Coordination of Humanitarian Affairs (UNOCHA) website. http://unispal.un.org/ UNISPAL.NSF/o/Do37818oCEC6DEFB85257D38oo543D5A (accessed July 23, 2021).

Yousef, Jabareen, (2015). The Rights to Space Production and the Right to Necessity: Insurgent Versus Legal Rights of Palestinians in Jerusalem. Planning Theory 16(1): $1-26$. 